\title{
Recent Developments in Environmental Law in Greece: A Commentary
}

\author{
Vasiliki-Maria Tzatzaki \\ Hellenic Ministry of Environment and Energy, Athens, Greece \\ Email address: \\ vickytzatzaki@gmail.com \\ To cite this article: \\ Vasiliki-Maria Tzatzaki. Recent Developments in Environmental Law in Greece: A Commentary. International Journal of Environmental \\ Protection and Policy. Vol. 8, No. 3, 2020, pp. 66-69. doi: 10.11648/j.ijepp.20200803.13
}

Received: June 5, 2020; Accepted: July 14, 2020; Published: August 4, 2020

\begin{abstract}
The recently voted environmental law in Greece (Law 4685/2020) aims to modernize and simplify the existing provisions and administrative procedures on various topics of national environmental regulation. The draft provisions underwent extensive public consultations with all interested stakeholders on the basis of transparency. The objective of this paper is to present Environmental Law 4685/2020; for methodological reasons, an analysis of each Chapter of the Law is being analyzed. Specifically, the Law comprises of eleven Chapters, each attempting to approach different issues, with 136 articles in total and two annexes, being one of the most ambitious revision proposals in the field of environmental legislation in Europe for the time being. The examination of the Chapters shows that the majority of its provisions stem from European Union legislation, with which Greece -as a member state- needs to comply. In this context, national provisions based on older Directives have been updated, while recent European Union Directives have been transposed, on the basis of new societal needs. The paper concludes that the new Environmental Law is an ambitious legislative framework, which sets more efficient regulatory models and faster procedures in Greece for the preservation of the ecosystems and the promotion of economic development at the same time.
\end{abstract}

Keywords: Environmental Law, Public Consultation, Modernization, Energy Resources, EU Directives

\section{Introduction}

On 6 May 2020 a new environmental law (Law 4685/2020) was voted by the Hellenic Parliament and the following day it was published in the Government Gazette (A 92/2020) [1]. The goal of this new legislation is to modernize and simplify the then existing legislative framework on various topics of national environmental regulation, such as environmental licensing, forest maps, waste management, renewable energy resources and management of protected areas. These specific areas were chosen for regulation, since they were the most problematic with regards to unnecessary administrative burden, long time frameworks for the completion of the procedures and heavy bureaucracy for the citizens.

The intention of drafting and passing a new environmental law was announced in October 2019 by the Hellenic Ministry of Environment and Energy and the draft provisions underwent extensive public consultations with all interested stakeholders, including co-competent authorities, the business sector, the civil society and non-governmental organizations. On the basis of transparency [2] and in order to promote the participatory approach [3], the draft law was uploaded on the relevant governmental internet platform, giving the opportunity to everyone to comment interactively and publicly for two weeks. Apart from that, during public consultations [4] proposals in written form were submitted to the competent authorities of the Ministry by stakeholders or interested parties.

Following public consultations, all comments were taken into account, duly examined and many of them were incorporated in the provisions. For the rejected comments, justifications and analysis were offered by the competent authorities to the Parliament in a special report regarding consultation, which can also be publicly accessed [5].

Specifically, Environmental Law 4685/2020 comprises of eleven Chapters with 136 articles in total and two annexes, being one of the most ambitious revisions in the field of environmental legislation in Europe for the time being. The majority of its provisions stem from European Union 
legislation, with which Greece -as a member state- needs to fully comply. In this context, national provisions based on older Directives have been updated, while recent European Union Directives have been transposed, on the basis of new and existing societal needs.

For methodological reasons, the present commentary will provide the reader with an overview of each Chapter of the new Law 4685/2020, highlighting the novelties in the legislation, the contribution to environment protection, as well as the promotion of the interests of the society.

\section{Analysis of Environmental Law $4685 / 2020$ by Chapter}

The first Chapter [6] of the Law deals with the simplification of the procedures for issuing environmental licenses and permits in Greece. According to the European Union legislation, a valid environmental permit is a sine qua non prerequisite for anyone who wants to proceed with activities or works. The permit is mandatory to rely on an Environmental Impact Assessment [7] and it needs to include all possible effects in the ecosystems as well as alternative scenarios.

The goal of the provisions of this Chapter is to give an end to the previous time consuming and bureaucratic procedures, in order to create an investment-friendly environment in the country. Fast procedures and the absolutely necessary paper work attract national and international investment, which the country needs in order to boost its economy and promote development.

This Chapter makes horizontal interventions in the then existing legislation, which introduce a faster, easier and more effective framework for environmental permits. Specifically, there are provisions for quicker and efficient renewal and modification of permits, as well as for the creation of a public registry, having individuals from the private sector as members that will assist the civil services, in accordance with the Directive 2011/92/EC [8].

The second Chapter [9] focuses on the promotion of renewable energy resources, which constitutes a vital goal for the European Union. According to the Directive 2018/2001/EU [10], the increased use of energy from renewable resources is a significant component of the measures that have to be adopted by member States so as to minimize gas emissions and adapt to the climate change goals of the Paris Agreement [11].

In this Chapter, as in the previous one, the provisions establish a simple licensing procedure for investors with the minimum paper work necessary and the digitalization of permit controls. The requirements put forward for a permit to be issued guarantee for no hindrances in the whole procedure and for no compromises in environmental protection at the same time.

In the third Chapter [12], a new operational model for the management of the country's protected areas [13] is introduced, since this modern system of governance appears to be the optimum tool for the preservation of these areas.
Thus, an integrated and unified structure has been chosen on the basis of existing good practices in other European countries, such as Finland and Austria and this is reflected in a new scientific, advisory and coordinating Organization.

The new institution bears the name 'Organization for Natural Environment and Climate Change' and it is under the auspices of the Hellenic Ministry of Environment and Energy. This Organization is going to be the central coordinator for all actions regarding protected areas in Greece, having 24 decentralized units, each corresponding to protected areas and it is going to cooperate with the rest co-competent authorities of public administration. This structure keeps the focal organizational point on a central level by creating the new institution and simultaneously enhances decentralization [14] by distributing competencies to the special units for the protected areas in Greece.

The next Chapter [15] goes hand in hand with the previous one, given that it regulates the use of land and activities within protected areas, redefining them and setting different protection levels, which correspond to updated general land uses. With these provisions, Greece abides by the Birds Directive (Directive 2009/147/EC) [16] and the Habitats Directive (Directive 92/43/EEC) [17] of the European Union, while setting new land use models.

Chapter five [18] makes amendments in the ratification and remodeling of forest maps, since the previous procedures proved to be problematic in their implementation, raising extra administrative onus and unfair treatment for citizens. The problem of setting forest maps stems from the practice of building construction within forests, resulting in social injustice and detrimental effects for the ecosystems.

In Decision 685/2019, the Hellenic State Council clearly stated that these illegal constructions, the so called residential densities, cannot be excluded from being registered in forest maps. Chapter's 6 provisions abide substantially by the aforementioned Decision and create a new regulatory framework for residential densities and forest maps [19].

Moreover, the seventh Chapter [20] transposes Directive (EU) 2018/844 of the European Parliament and of the Council of 30 May 2018 amending Directive 2010/31/EU on the energy performance of buildings and Directive 2012/27/EU on energy efficiency, while Chapter 8 [21] transposes Directive 2019/692/EU for the amendment of the Directive 2009/73/EC [22], regarding the common rules for the internal natural gas market and thus, Greece fully complies with the European Union legislation in this matter.

Furthermore, the ninth Chapter [23] deals with several administrative issues within the Hellenic Cadaster and attempts to resolve them, making more efficient its operation and consequently, its daily interaction with the citizens.

Chapter ten [24] is very important for the population of the country, since it regulates issues of waste management. In particular, the provisions of this Chapter amend previous ones in order to establish a modern framework for the approval of National, Peripheral and Local Waste Management Plans [25]. Also, some of its provisions regulate the shedding of construction debris in order not to be 
disposed in the streets, parks or watercourses. In such a way, the urban, cultural and natural environment is being protected from a common malpractice.

Moreover, this Chapter includes provisions for sound waste management in the Greek islands. During summer, when tourism is in its peak, waste is not disposed properly due to the lack of facilities and human resources, resulting in the aesthetic degradation of the islands and serious health concerns. This is not a new issue and many attempts have been made in order to combat it, since the Greek islands are the major source and basic pillar for promoting the country's tourism and economy.

The final Chapter [26] has provisions on various environmental matters of great importance, such as financial subsidies to the residents when connecting their houses with the central waste water treatment pipelines in accordance with the Directive 91/271/EEC [27], as well as the imposition of environmental fee in all plastic bags, regardless of their size, starting from the $1^{\text {st }}$ of January 2021, according to the Directive 2015/720/EU [28].

\section{Conclusion}

On the basis of the aforementioned, the recently voted Environmental Law 4685/2020 in Greece appears to be a highly promising legal framework for the modernization of procedures, the mitigation of administrative burden and the facilitation of public services for citizens. It constitutes an important first step to the abolition of obsolete practices and the adoption of a quicker and more coherent way of public operation. Of course, the responsibility for the correct implementation of the provisions rests mainly in the public authorities, which have to adapt to the new status quo and adhere to it. Overall, the success of this legislative attempt remains to be seen in future and in practice, both in terms of the administrative model as well as of the ecological protection framework.

\section{References}

[1] Law 4685/2020 "Modernization of environmental legislation, integration into the Greek legislation of the Directives 2018/844 and 2019/692 of the European Parliament and the Council and other provisions", Government Gazette A 92, 07 May 2020.

[2] R. Adams, Transparency: New Trajectories in Law, New York, NY: Routledge, 2020 and D. Berliner (2014). The Political Origins of Transparency, The Journal of Politics, 76: 479-491.

[3] I. Kapoor (2001). Towards Participatory Environmental Management, Journal of Environmental management 63: 269279.

[4] Organisation for Economic Co-operation and Development "Citizens as Partners. Information, Consultation and Public Participation in Policy-Making”, Paris: OECD, 2001.

[5] See https://www.hellenicparliament.gr/UserFiles/2f026f42950c-4efc-b950-340c4fb76a24/perivallontos-olo.pdf (in Greek).
[6] Law 4685/2020 "Modernization of environmental legislation, integration into the Greek legislation of the Directives 2018/844 and 2019/692 of the European Parliament and the Council and other provisions", Government Gazette A 92, 07 May 2020, articles 1-9.

[7] A. Morrison-Saunders, Advanced Introduction to Environmnental Impact Assessment, Cheltenham: Edward Elgar Publishing, 2018.

[8] Directive 2011/92/EU of the European parliament and of the council of 13 December 2011 on the assessment of the effects of certain public and private projects on the environment (consolidated text), available at https://eur-lex.europa.eu/legalcontent/EN/TXT/PDF/?uri=CELEX:02011L0092$20140515 \&$ from $=\mathrm{EN}$.

[9] Law 4685/2020 "Modernization of environmental legislation, integration into the Greek legislation of the Directives 2018/844 and 2019/692 of the European Parliament and the Council and other provisions", Government Gazette A 92, 07 May 2020, articles 10-25.

[10] Directive (EU) 2018/2001 of the European Parliament and of the Council of 11 December 2018 on the promotion of the use of energy from renewable sources, available at https://eurlex.europa.eu/legalcontent/EN/TXT/PDF/?uri=CELEX:32018L2001\&from=EN.

[11] Paris Agreement, signed 12 December 2015, entry into force 4 November 2016, available at https://treaties.un.org/doc/Publication/UNTS/No\%20Volume/5 4113/Part/I-54113-0800000280458f37.pdf.

[12] Law 4685/2020 "Modernization of environmental legislation, integration into the Greek legislation of the Directives 2018/844 and 2019/692 of the European Parliament and the Council and other provisions", Government Gazette A 92, 07 May 2020, articles 26-43.

[13] A. Gillespie, Protected Areas and International Environment Law, The Netherlands: BRILL, 2007, A. Jackson, Conserving Europe's Wildlife: Law and Policy of the Natura 2000 Network of Protected Areas, London: Routledge, 2018 and K. Bastmeijer (ed.), Wilderness Protection in Europe. The Role of International, European and National Law, Cambridge: Cambridge University Press, 2016.

[14] M. Isufaj (2014). Decentralization and the Increased Autonomy in Local Governments, Procedia-Social and Behavioral Sciences 109: 459-463.

[15] Law 4685/2020, "Modernization of environmental legislation, integration into the Greek legislation of the Directives 2018/844 and 2019/692 of the European Parliament and the Council and other provisions", Government Gazette A 92, 07 May 2020, articles 44-47.

[16] Directive 2009/147/EC of the European Parliament and of the Council of 30 November 2009 on the conservation of wild birds (codified version), available at https://eurlex.europa.eu/legalcontent/EN/TXT/PDF/?uri=CELEX:32009L0147\&from=EN.

[17] Council Directive 92/43/EEC of 21 May 1992 on the conservation of natural habitats and of wild fauna and flora (consolidated version), available at https://eurlex.europa.eu/legalcontent/EN/TXT/PDF/?uri=CELEX:01992L004320130701\&from $=\mathrm{EN}$. 
[18] Law 4685/2020, "Modernization of environmental legislation, integration into the Greek legislation of the Directives 2018/844 and 2019/692 of the European Parliament and the Council and other provisions", Government Gazette A 92, 07 May 2020, articles 48-49.

[19] Law 4685/2020, "Modernization of environmental legislation, integration into the Greek legislation of the Directives 2018/844 and 2019/692 of the European Parliament and the Council and other provisions", Government Gazette A 92, 07 May 2020, articles 50-55.

[20] Law 4685/2020, "Modernization of environmental legislation, integration into the Greek legislation of the Directives 2018/844 and 2019/692 of the European Parliament and the Council and other provisions", Government Gazette A 92, 07 May 2020, articles 56-71.

[21] Law 4685/2020, "Modernization of environmental legislation, integration into the Greek legislation of the Directives 2018/844 and 2019/692 of the European Parliament and the Council and other provisions", Government Gazette A 92, 07 May 2020, articles 72-73.

[22] Directive (EU) 2019/692 of the European Parliament and of the Council of 17 April 2019 amending Directive 2009/73/EC concerning common rules for the internal market in natural gas, available at https://eur-lex.europa.eu/legalcontent/EN/TXT/PDF/?uri=CELEX:32019L0692\&from=EN.

[23] Law 4685/2020, "Modernization of environmental legislation, integration into the Greek legislation of the Directives
2018/844 and 2019/692 of the European Parliament and the Council and other provisions", Government Gazette A 92, 07 May 2020, articles 74-82.

[24] Law 4685/2020, "Modernization of environmental legislation, integration into the Greek legislation of the Directives 2018/844 and 2019/692 of the European Parliament and the Council and other provisions", Government Gazette A 92, 07 May 2020, articles 83-95.

[25] European Commission, Directorate General Environment, Preparing a Waste Management Plan. A Methodological Guidance Note, 2012, available at https://ec.europa.eu/environment/waste/plans/pdf/2012_guida nce_note.pdf.

[26] Law 4685/2020, "Modernization of environmental legislation, integration into the Greek legislation of the Directives 2018/844 and 2019/692 of the European Parliament and the Council and other provisions", Government Gazette A 92, 07 May 2020, articles 96-136.

[27] Council Directive of 21 May 1991 concerning urban waste water treatment (91/271/EEC, consolidated version), available at COUNCIL DIRECTIVE of 21 May 1991 concerning urban waste water treatment (91/271/EEC).

[28] Directive (EU) 2015/720 of the European Parliament and of the Council of 29 April 2015 amending Directive 94/62/EC as regards reducing the consumption of lightweight plastic carrier bags, available at https://eur-lex.europa.eu/legalcontent/EN/TXT/PDF/?uri=CELEX:32015L0720\&from=EN. 